\title{
A Phase I Cultural Resource Survey for the Proposed Six Mile Boat Ramp Expansion Project (Texas Antiquities Permit \#9155)
}

Jay W. Gray

Jennifer M. Haney

Follow this and additional works at: https://scholarworks.sfasu.edu/ita

Part of the American Material Culture Commons, Archaeological Anthropology Commons, Environmental Studies Commons, Other American Studies Commons, Other Arts and Humanities Commons, Other History of Art, Architecture, and Archaeology Commons, and the United States History Commons

Tell us how this article helped you.

This Article is brought to you for free and open access by the Center for Regional Heritage Research at SFA ScholarWorks. It has been accepted for inclusion in Index of Texas Archaeology: Open Access Gray Literature from the Lone Star State by an authorized editor of SFA ScholarWorks. For more information, please contact cdsscholarworks@sfasu.edu. 


\section{A Phase I Cultural Resource Survey for the Proposed Six Mile Boat Ramp Expansion Project (Texas Antiquities Permit \#9155)}

\section{Creative Commons License}

\section{(c) (1) \&}

This work is licensed under a Creative Commons Attribution-NonCommercial 4.0 International License 


\section{A PHASE I CULTURAL RESOURCE SURVEY FOR THE PROPOSED SIX MILE BOAT RAMP EXPANSION PROJECT (TEXAS ANTIQUITIES PERMIT \#9155)}
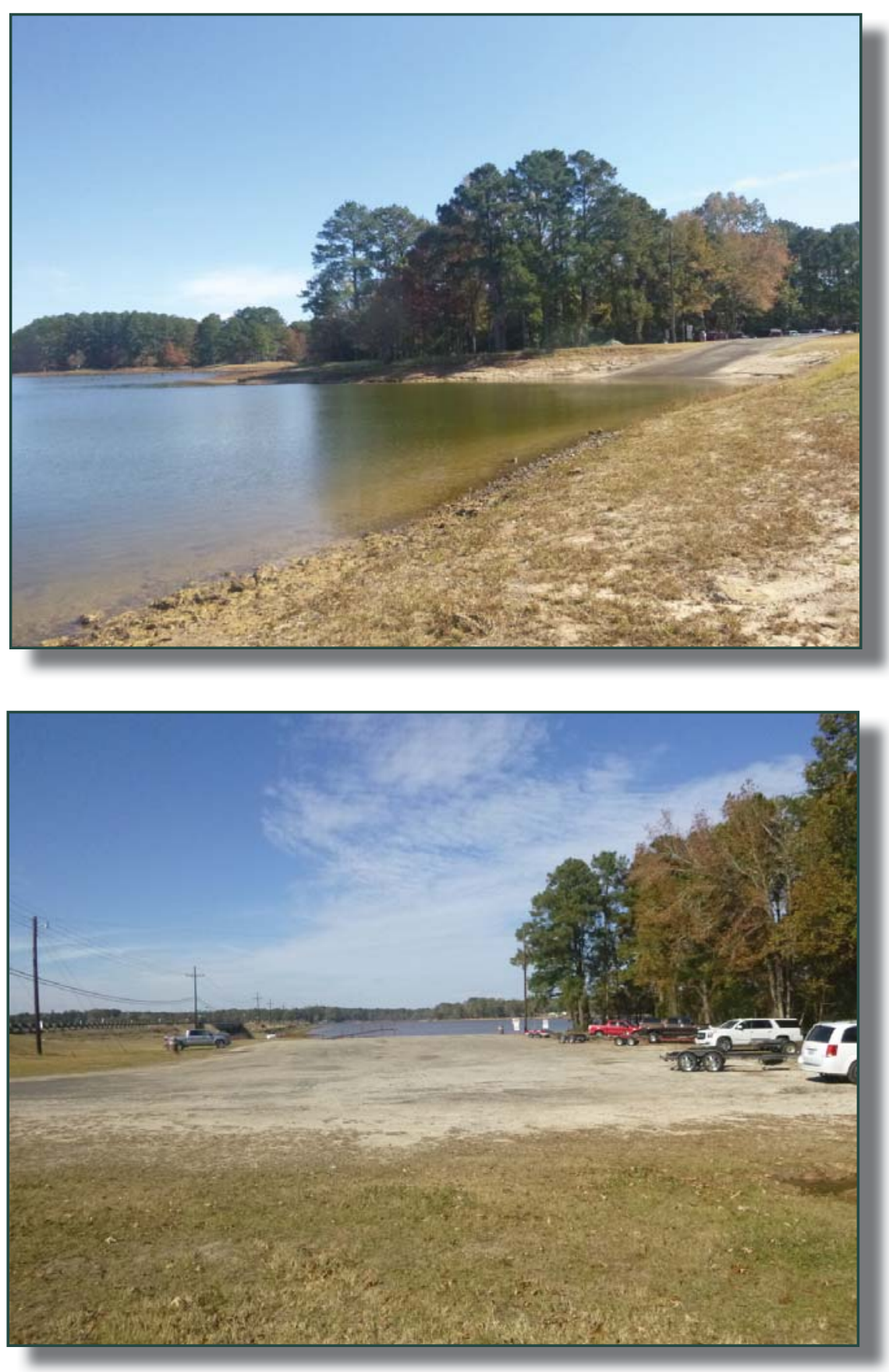

by

Jay W. Gray, RPA 989602

and

Jennifer M. Haney, RPA 15209

Prepared for

Sabine River Authority of Texas 



\title{
A PHASE I CULTURAL RESOURCE SURVEY FOR THE PROPOSED SIX MILE BOAT RAMP EXPANSION PROJECT (TEXAS ANTIQUITIES PERMIT \# 9155)
}

\author{
By \\ Jay W. Gray, RPA 989602 \\ and \\ Jennifer M. Haney, RPA 15209
}

Prepared for

Sabine River Authority of Texas

12777 Highway 87 North

Orange, Texas 77632

Prepared by

Cultural Resource Analysts, Inc. 9105 Avalon Drive

Shreveport, Louisiana 71118

Phone: (318) 213-1385

Email: jwgray@crai-ky.com

CRA Project No.: L19S002

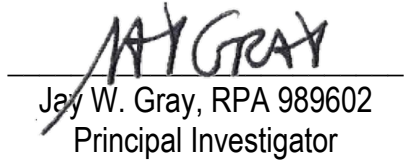

March 25, 2020 



\section{MANAGEMENT SUMMARY}

Cultural Resource Analysts, Inc., personnel completed a records review and cultural resource survey for the proposed expansion of the existing Six Mile Boat Ramp in Sabine County, Texas. This work was performed to assist the Sabine River Authority of Texas in complying with Section 106 of the National Historic Preservation Act of 1966 (Public Law 89-665, 16 U.S.C. 470h-2) as an applicant for a Section 404 Clean Water Act Permit from the US Army Corps of Engineers, and the provisions of the Texas Administrative Code regarding archaeological resources on public lands. The Texas Administrative Code requires review of projects on state-owned lands by the Texas Antiquities Commission. The Sabine River Authority of Texas is considered a political subdivision of the State of Texas, and therefore it has a responsibility to provide the Texas Antiquities Commission an opportunity to review projects that may affect potential or designated archaeological sites. This project was performed under Texas Antiquities Permit (No. 9155). All work was performed pursuant to the guidelines published by the Council of Texas Archeologists and adopted by the Texas Historical Commission, and this report was prepared following the short report format in the Guidelines for Cultural Resource Management Reports published by the Council of Texas Archeologists.

The current proposed project includes the expansion of the Six Mile Boat Ramp on the Toledo Bend Reservoir in Sabine County, Texas. The proposed development includes the addition of a handicap-accessible floating boat ramp, the clearing of approximately 0.4 ha $(1.0$ acre $)$ of trees, the construction of a parking area, the addition of a vault toilet, the addition of two tables on concrete platforms, and the clearing of trees along the shoreline to provide an enhanced scenic view. In order to provide some flexibility in siting these facilities, the direct and visual areas of potential effect for this project were within a polygon adhering on its southern and western boundaries to the property line, and roughly buffered to the north and east by the existing shoreline of the Toledo Bend Reservoir. It is estimated that the area of potential effect for this project measures 1.2 ha (3.0 acres), of which approximately 0.9 ha (2.2 acres) could be surveyed, excluding paved surfaces.

The records review for this project was conducted on October 18,2019, prior to the commencement of the field survey, to identify cultural resources or cultural resource investigations previously documented within the area. This file search utilized online files maintained by the Texas Archaeological Research Laboratory at the University of Texas. Additionally, historic maps were examined to identify the locations of any potential historic archaeological sites. The records review indicated that one previously documented site, $41 \mathrm{SB} 58$, was located within approximately $50 \mathrm{~m}$ (164 $\mathrm{ft}$ ) to the north of the proposed project area. Additionally, one historic structure was depicted within the project area on historic mapping.

Fieldwork was conducted on November 19, 2019, and was completed in 11.5 person hours. The project area was systematically investigated by pedestrian survey and screened shovel tests spaced at a $30 \mathrm{~m}$ (98 ft) interval on pedestrian transects spaced at $30 \mathrm{~m}$. The fieldwork for this project resulted in one newly recorded isolated find that is not eligible for designation as a Texas State Archeological Landmark or for listing in the National Register of Historic Places. Based on the findings of this work, it is recommended that the project area be considered cleared from a cultural resource perspective. 
Page intentionally left blank. 


\section{TABLE OF CONTENTS}

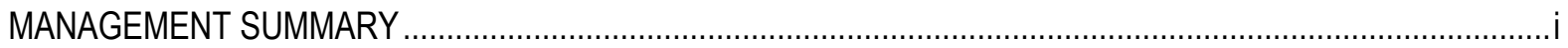

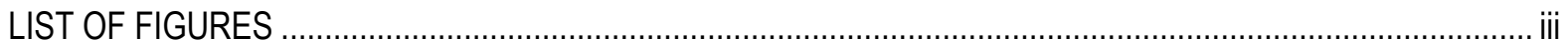

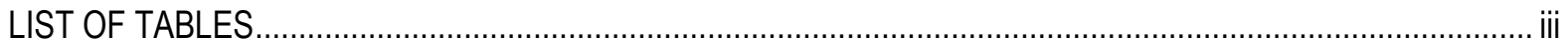

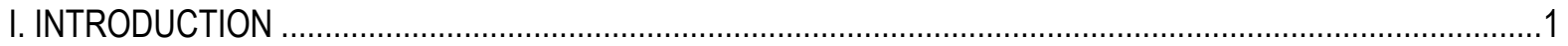

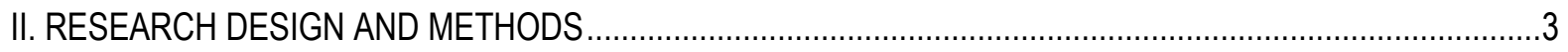

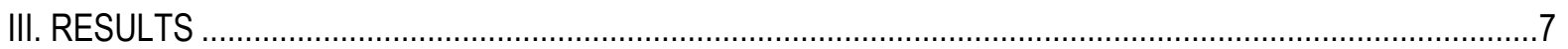

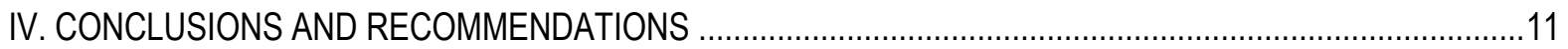

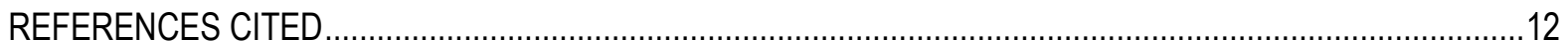

APPENDIX A. TOPOGRAPHIC MAP SHOWING PREVIOUSLY DOCUMENTED SITES WITHIN $1.6 \mathrm{KM}$ (1.0 MI)

OF THE PROJECT AREA (NOT FOR PUBLIC DISCLOSURE) .........................................................

APPENDIX B. TOPOGRAPHIC MAP SHOWING NEWLY RECORDED RESOURCES (NOT FOR PUBLIC

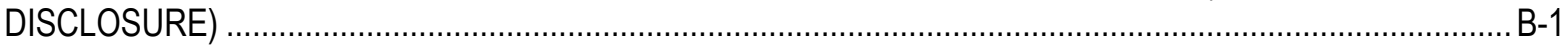

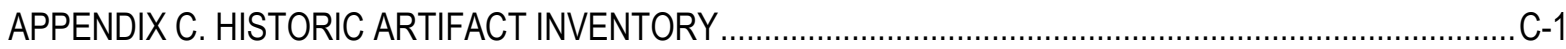

\section{LIST OF FIGURES}

Figure 1. Map showing the location of Sabine County in the state of Texas..................................................

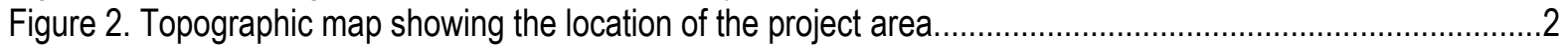

Figure 3. Shovel testing transect locations as depicted on aerial imagery......................................................

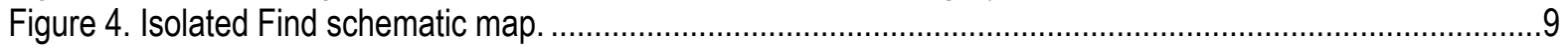

Figure 5. Items collected during the survey: a) salt-glazed stoneware; b) chromatic glaze and salt stoneware; $c$ ) chert specimen \#3-34.58 g; d) chert specimen \#1-226 g; and e) chert specimen \#2-100.11 g.......................10

Figure A-1. Map showing the previously documented sites within $1.6 \mathrm{~km}(1.0 \mathrm{mi})$ of the project area (Not for Public Disclosure).

Figure B-1. Topographic quadrangle map showing the location of newly recorded resources (Not for Public Disclosure).

\section{LIST OF TABLES}

Table 1. Data on Sites within $1.6 \mathrm{~km}$ of Project Area. 7

Table C-1. Historic Materials Recovered. 
Page intentionally left blank. 


\section{INTRODUCTION}

C ultural Resource Analysts, Inc. (CRA), personnel completed a records review and cultural resource survey for the proposed expansion of the existing Six Mile Boat Ramp in Sabine County, Texas (Figure 1). This work was performed under contract with the Sabine River Authority of Texas (SRA-TX) on property owned by the SRA-TX adjacent to the Toledo Bend Reservoir (Figure 2). The work was performed under Texas Antiquities Permit Number 9155.

The fieldwork for this project was conducted on November 19, 2019, and took 11.5 person hours to complete. Tasks fulfilled during the cultural resource survey included surface and subsurface archaeological survey, and the delineation and recording of identified cultural resources. Jeremy W. Pye, PhD, RPA, served as the field supervisor and was accompanied by Jay Nash. Artifact analysis was performed by Jennifer M. Haney, PhD, RPA, who also assisted with report authorship. Li Bai prepared the field and report mapping. Jay W. Gray, MA, RPA, served as the principal investigator and primary report author.

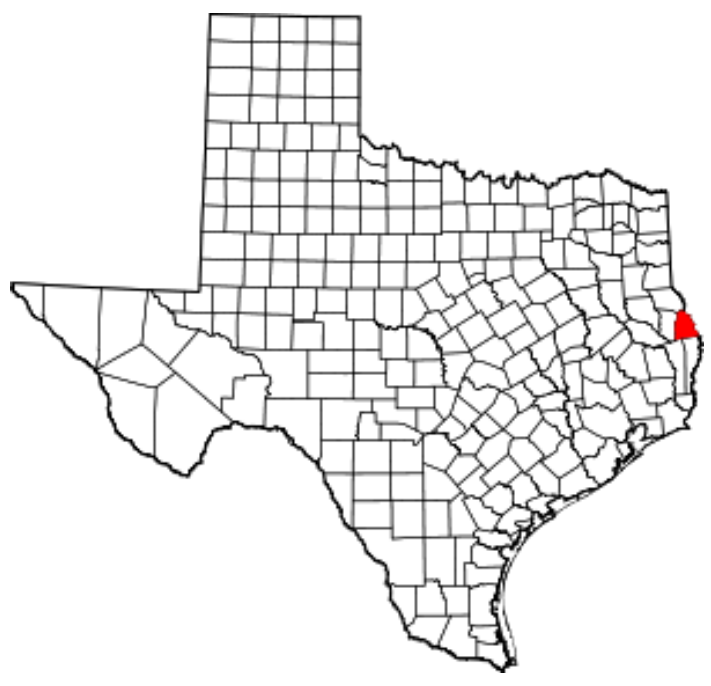

Figure 1. Map showing the location of Sabine County in the state of Texas.
Field investigations were performed pursuant to the standards published by the Council of Texas Archeologists (CTA) and adopted by the Texas Historical Commission (THC), acting on behalf of the State Historic Preservation Office (SHPO). This report follows the short report format as outlined by the CTA's Guidelines for Cultural Resource Management Reports. All materials associated with this project will be prepared for permanent curation at Stephen F. Austin State University.

\section{Project Description}

The proposed expansion included the addition of a handicap-accessible floating boat ramp, the clearing of approximately 0.4 ha (1.0 acre) of trees, the construction of a parking area, the addition of a vault toilet, the addition of two tables on concrete platforms, and the clearing of trees along the shoreline to provide an enhanced scenic view. The construction of these facilities would have a small impact horizontally, and most of the construction would have a very shallow vertical impact with the exception of the vault toilet which would require the excavation of a pit. In order to provide some flexibility in siting these facilities, the direct area of potential effect (APE) for this project was considered an area demarcated to the south and west by the SRA-TX property line, and to the north and east by the existing shoreline of the Toledo Bend Reservoir. It is estimated that the direct APE for this project includes 1.2 ha ( 3 acres), of which approximately 0.3 ha $(0.8$ acre) was under pavement at the time of the survey, and thus 0.9 ha (2.2 acres) underwent survey. The locations of the proposed facilities were not finalized by the completion of the field investigation and reporting, but they will be entirely within the direct APE as defined for this project. The vertical APE for archaeology would include all the sediment above the subsoil within the direct APE since it is unclear where the vault toilet will be placed. The impact to historic-age aboveground resources was also taken into consideration, and it was determined that the visual APE was limited to the direct APE as defined above. There were no buildings or structures over 50 years in age within the visual APE for this project. 


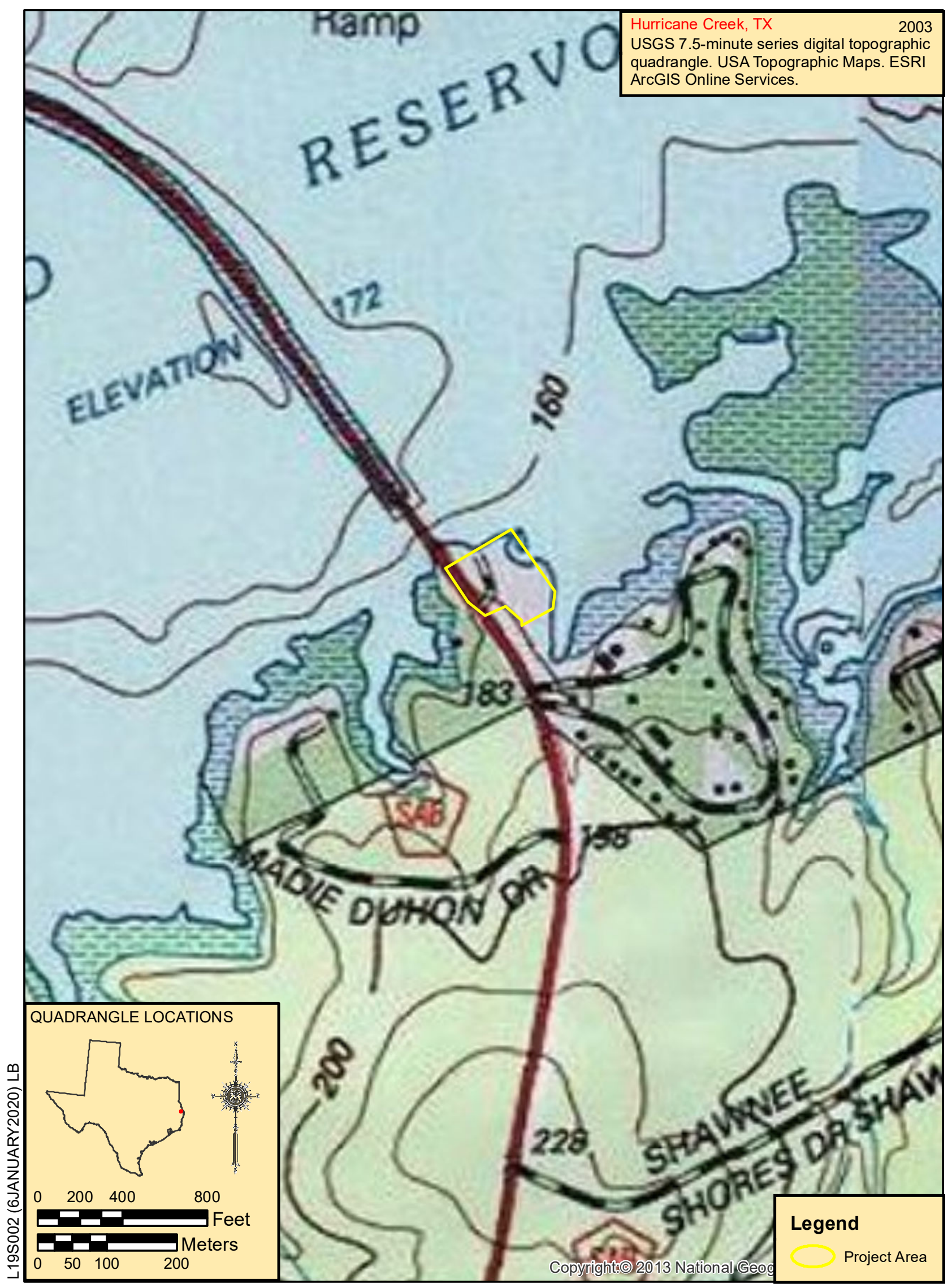

Figure 2. Topographic map showing the location of the project area. 


\section{Purpose of Study}

This work was performed to assist the Sabine River Authority of Texas in complying with Section 106 of the National Historic Preservation Act of 1966 (Public Law 89-665, 16 U.S.C. 470h-2) (NHPA) as an applicant for a Section 404 Clean Water Act Permit from the US Army Corps of Engineers, and the provisions of the Texas Administrative Code regarding archaeological resources on public lands. In accordance with 33 CFR Part 325, the US Army Corps of Engineers required that the SRA-TX performs a cultural resource investigation to locate any historic properties that may be adversely affected. The Antiquities Code of Texas (Texas Natural Resource Code, Title 9, Chapter 191) and accompanying Rules of Practice and Procedure (Texas Administrative Code, Title 13, Chapter 26) require review of projects on state-owned lands by the Texas Antiquities Commission (TAC). The SRA-TX is considered a political subdivision of the State of Texas, and therefore it has a responsibility to provide the TAC an opportunity to review projects that may affect potential or designated archaeological sites.

\section{RESEARCH DESIGN AND METHODS}

$T$ his section describes the research goals and methods used during the cultural resource survey.

\section{Research Design}

The most basic research goal of the project was to locate, describe, and make appropriate recommendations for the future treatment of any archaeological site that may be adversely affected within the project APE. Each located cultural resource within the project APE was also evaluated for its eligibility as a State Archeological Landmark and for listing in the National Register of Historic Places (NRHP). Under the NHPA, historic properties include prehistoric or historic districts, sites, buildings, structures, or objects that are listed in or eligible for listing in the NRHP, and projects permitted by federal agencies must take into consideration the project effects upon these resources. Sites that are designated as or eligible for designation as State Archeological Landmarks may not be "removed, altered, damaged, destroyed, salvaged, or excavated" without first obtaining a permit from the THC.

\section{Records Review}

A file search consisting of a review of records of files maintained by the THC on the Texas Archeological Site Atlas was conducted to: 1) determine if the project areas had been previously surveyed for cultural resources; 2) identify any previously recorded cultural resources that were situated within the project areas; 3 ) provide information concerning what, if any, cultural resources might be expected within the project areas; and 4) provide a context for interpreting any cultural resources identified within the project areas. This work also included a review of maps and records of historic structures and archaeological sites for an area encompassing a $1.6 \mathrm{~km}(1.0 \mathrm{mi})$ radius beyond the current project area.

\section{Field Investigation}

Determining the locations of cultural resources within the project area relied upon a cultural survey performed according to the guidelines set forth by the CTA and adopted by the THC. Under the Antiquities Code of Texas, State Archeological Landmarks may include "sites, objects, buildings, artifacts, implements, and locations of historical, archeological, scientific, or educational interest, including those pertaining to prehistoric and historical American Indians or aboriginal campsites, dwellings, and habitation sites, their artifacts and implements of culture, as well as archeological sites of every character" that are designated as, or eligible for designation as, a State Archeological Landmark.

Site significance was determined through investigation at individual resources to determine site boundaries, depths of artifact burial, and presence or absence of cultural stratigraphy and features. According to the Antiquities Code of Texas, State Archeological 
Landmark Eligibility is determined by the historical significance of the archaeological site to the history or prehistory of Texas or to the United States. Compliance with Section 106 of the NHPA requires a recommendation on whether or not any identified cultural resources may represent historic properties that are eligible for listing in the NRHP, and that adverse project effects on these resources be identified.

\section{Artifact Analysis}

The goals of artifact analysis for survey-level documentation were primarily focused on chronological placement of each archaeological site into temporal periods and archaeological phases whenever possible. Insomuch as individual site assemblages allowed, additional goals included discerning the range and types of activities performed at individual sites and making inferences about occupation intensity to aid in assessments of site function.

\section{Methods}

Field Methods

The entire project area was systematically investigated by a combination of intensive pedestrian survey and shovel tests (Figure 3). The project area was considered to have a high probability of containing cultural resources, and therefore shovel tests were spaced at a $30 \mathrm{~m}$ (98 ft) interval on pedestrian transects spaced at $30 \mathrm{~m}$. Shovel tests were circular holes measuring $35.0 \mathrm{~cm}$ (13.8 in) in diameter excavated in zones not exceeding $20 \mathrm{~cm}$ (8 inches), and excavated to sterile subsoil, or to a minimum depth of $80 \mathrm{~cm}$ (31 in) below ground surface (bgs) if subsoil was not encountered. All fill removed from the tests was screened through $0.64 \mathrm{~cm}$ ( $0.25 \mathrm{in})$ mesh hardware cloth, exposed profiles in each shovel test were recorded on standardized recording forms, and the sidewalls and bottoms of the shovel tests were examined for artifacts, potential cultural soil horizons, and features.

Upon excavation of a survey shovel test yielding cultural material or the discovery of surface artifacts, this location was arbitrarily assigned a field site/delineation number. The positive survey shovel test or surface find at each field site was designated as the grid origin and assigned a coordinate of N1000 E1000. Site boundary recordation relied on a combination of visual examination of surface exposures to delimit the extent of artifacts in surface contexts and shovel testing to delimit the extent of subsurface artifacts. Delineation shovel tests were excavated around the datum point at an interval of $10 \mathrm{~m}$ (32 $\mathrm{ft}$ ) and were excavated in $10 \mathrm{~cm}$ (4 in) levels with artifacts from each level bagged separately. Site boundaries were determined by the excavation of two negative shovel tests beyond each positive shovel test and the extent of the surface scatter of artifacts or features within the project area boundaries. Sketch maps were drawn to scale during each site delineation. These maps included the locations of positive and negative shovel tests, the extent of surface artifacts and cultural features, topographic and environmental information, and project boundaries. Photographs of each site were taken to illustrate the field conditions at the time of the survey.

Universal Transverse Mercator (UTM) coordinates were recorded using ESRI ArcPad 11 software on a GeoExplorer 3000 Series GeoXT handheld global positioning system (GPS) unit manufactured by Trimble to verify locations within the project area with greater than $\pm 5 \mathrm{~m}$ (16 $\mathrm{ft}$ ) accuracy. Data were collected using the North American Datum (NAD) 1983 projection. The locations of all delineation shovel tests, site datums, cultural features, and site boundary shape files were recorded in this manner. Site boundaries were recorded as polygon files, while shovel test locations, site datums, and aboveground features were collected as point or line files.

\section{Laboratory Methods}

This section provides a detailed discussion of the methods used in CRA's laboratory. This discussion incorporates details of the theoretical approaches used to assign artifacts to categories with formal, temporal, regional, and functional implications from which cultural interpretations may be made. Additional details regarding the regional typologies and functional groups can be found in individual site descriptions in the Results Section, where the analytical results are provided. Additional analytical data on each class of artifacts are also provided in the appendices of this report. 


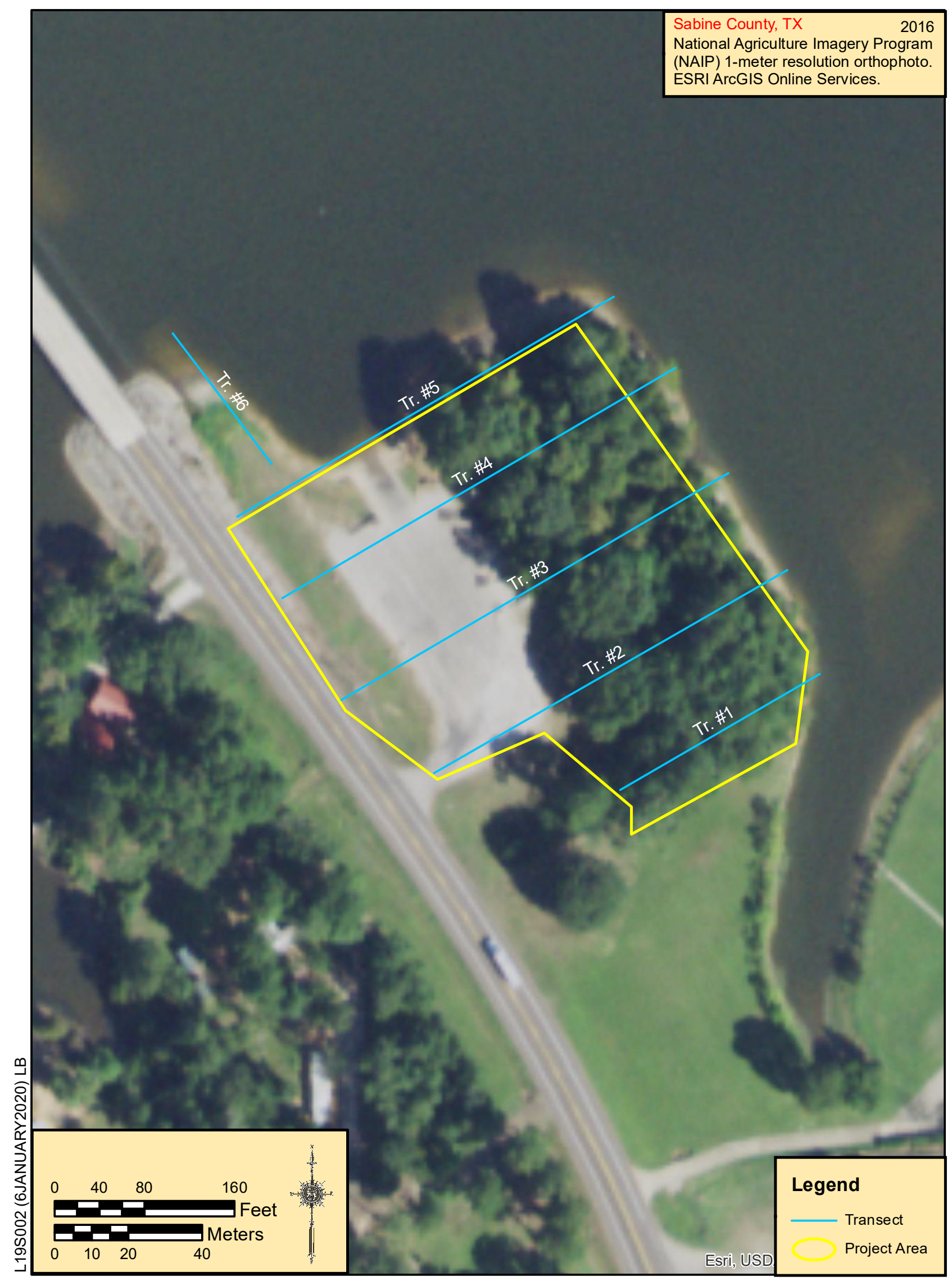

Figure 3. Shovel testing transect locations as depicted on aerial imagery. 
All cultural materials recovered from the project were transported to CRA's Louisiana Office for processing and analysis. Initial processing of the recovered artifacts involved washing the artifacts with city tap water and sorting the artifacts into the major material classes (i.e., pottery, faunal, historic, and lithic) for further analysis. Delicate items, such as faunal remains, were dry brushed to remove any loose soil. Following the initial processing of artifacts, detailed analysis was undertaken. The analysis methods and specifics of classification for each class of materials is discussed under the relevant headings in the Historic Materials section below. All artifacts, field notes, records and project/site photographs will be curated at Stephen F. Austin State University. Artifact catalog numbers were applied using both a base coat and top coat of Paraloid B-72 lacquer (25\% solution of acryloid B-72 in acetone) and India ink.

\section{Historic Materials}

The historic assemblage includes artifacts classified and grouped according to a scheme originally developed by Stanley South (1977). South believed that his classification scheme would present patterns in historic site artifact assemblages that would provide cultural insights. Questions of historic site function, the cultural background of a site's occupants, and regional behavior patterns were topics to be addressed using this system.

Information on the age of artifacts as described in the artifact tables is derived from a variety of sources cited in the discussion of the materials recovered. The beginning and ending dates cited need some clarification. Usually, an artifact has specific attributes that represent a technological change, an invention in the manufacturing process, or simple stylistic changes in decoration. These attribute changes usually have associated dates derived from historical and archaeological research. For example, bottles may have seams that indicate a specific manufacturing process patented in a certain year. The bottle then can be assigned a "beginning," or incept, date for the same year of the patent. New technology may eliminate the need for the same patent and the bottle would no longer be produced. The "ending," or terminal, date will be the approximate time when the new technology took hold and the older manufacturing processes were no longer in use.

Specific styles in ceramic decorations are also known to have changed. Archaeological and archival researchers have defined time periods when specific ceramic decorations were manufactured and subsequently went out of favor (e.g., Lofstrom et al. 1982; Majewski and O'Brien 1987). South's (1977) mean ceramic dating technique uses this information. The dates presented here should not be considered absolute, but rather as the best estimates of an artifact's age available at this time. A blank space indicates that the artifact could not be dated or, alternately, that the period of manufacture was so prolonged that the artifact was being manufactured before North America was colonized. An open-ended terminal date was assigned for artifacts that may be acquired today. The rationale for presenting dates for the artifacts recovered is to allow a more precise estimate of the time span during which the site was occupied, rather than the mean occupation date of a site.

\section{Domestic Group}

Artifacts included in the domestic group consist of ceramics, container glass, container closures, glass tableware, utensils, cookware, housekeeping, metal food containers, other cookware, and undiagnostic container glass.

\section{Ceramics}

The recovered ceramics consisted of only a single ware: stoneware.

\section{Stoneware}

Stoneware served as the "daily use" pottery of America, particularly of rural America, after its introduction during the last decade of the eighteenth century. By 1850, this ware generally replaced coarse redware as the primary utilitarian ware used in American households. Stoneware is a semi-vitreous ware manufactured of a naturally fine, but dense, clay. The pottery was fired longer and to a 
higher temperature than earthenwares; a kiln temperature of at least 1,200 to 1,250 degrees Celsius had to be obtained (Cameron 1986:319; Dodd 1964:274-275). As a result, stoneware generally exhibits a hard body and a very homogeneous texture. The paste may vary from gray to brown, depending on the clay source, and length and intensity of the firing.

Because this ware is fired at such high temperatures, its body is nonporous and well suited to liquid storage. Stoneware, as mentioned, was not typically manufactured as a refined ware (such as its cousin, ironstone, or eighteenth-century refined white salt-glazed stoneware), and hence, it was for the most part utilized for utilitarian activities associated with jars, churns, crocks, tubs, jugs, mugs, pans, and pots. These vessels were typically glazed, with salt glazing and slip glazing being most common.

Although refined salt glazing was practiced in England during the eighteenth century, by 1780 , the production of English salt-glazed tableware had been virtually supplanted by the manufacture of cream colored earthenwares (Lewis 1950:29). The salt-glazing technique continued to be utilized for utilitarian vessels, however, and was eventually introduced to the United States in the early nineteenth century. Salt glazing was accomplished by introducing sodium chloride into the kiln during the firing process, at which point the salt quickly volatilized. The vapor reacted with the clay to form a sodium aluminum silicate glaze (see Billington 1962:210; Dodd 1964:239). The surface of the glaze is typically pitted, having what is commonly known as an "orange peel" effect.

\section{RESULTS}

$\Delta \mathrm{s}$ a result of the cultural resource survey, one isolated find was recorded within the project area. The findings of the records review, and the field and laboratory investigations are discussed below.

\section{Records Review}

The records review indicated that the proposed development area has not previously undergone cultural resource survey, and did not contain any previously recorded archaeological sites or extant buildings or structures of historic age (greater than 50 years old). In total, eight previously documented sites exist within $1.6 \mathrm{~km}$ of the project area (Table 1). One previously documented site lies within close proximity to the project APE. Site 41SB58 was previously recorded by Scurlock and Davis during the Toledo Bend reconnaissance survey as having been a small, temporary prehistoric camp along the edge of Six Mile Creek, and test units at the site yielded two sherds and three pieces of debitage. This site was mapped on the Texas Archaeological Sites Atlas at the terminus of the exposed landform on which the proposed project is situated, within approximately $50 \mathrm{~m}(164 \mathrm{ft})$ of the northern edge of the APE. During a revisit to the site by Soltysiak during the Toledo Bend Project Federal Energy Regulatory Commission (FERC) relicensing, visual inspection of the mapped location of the site did not reveal any additional artifacts, and the state site form indicates that it was believed to be inundated farther to the north, under the waters of the Toledo Bend Reservoir. Both of the previous studies recommended that the site should not be considered for any additional archaeological work.

Table 1. Data on Sites within $1.6 \mathrm{~km}$ of Project Area.

\begin{tabular}{|c|c|c|c|c|c|}
\hline Trinomial & Gross Component & Specific Component & Site Type & Landform & Notes \\
\hline 41SB58 & Prehistoric & Late Prehistoric (ceramics present) & Campsite & Floodplain & \\
\hline 41SB66 & Prehistoric & $\begin{array}{l}\text { Archaic, Late Prehistoric (ceramics present), } \\
\text { and 20th c. historic }\end{array}$ & Open (campsite) & Circular ridge & \\
\hline $41 \mathrm{SB} 40$ & Prehistoric & Late Prehistoric (ceramics present) & Mound & Bottom land & $125 \mathrm{ft}$ in dia., $15 \mathrm{ft}$ in height \\
\hline 41SB41 & Prehistoric & Late Prehistoric (ceramics present) & Natural mounds & Bottom land & 4 small mounds, $50 \mathrm{ft}$ in dia., $8 \mathrm{ft}$ in height \\
\hline 41SB138 & Prehistoric & No Data & & No Data & No site form available \\
\hline 41SB137 & Prehistoric & No Data & & No Data & No site form available \\
\hline 41SB135 & Prehistoric & No Data & & No Data & No site form available \\
\hline
\end{tabular}


An examination of historic maps and other historic documents available for the project area indicates that the project area was part of a large, 4,428.4-acre tract originally titled to Eli Lowe (Low) in 1835 by the Estado Libre De Coahila Y Tejas (Patent No. 665, Volume 22, p. 861). The earliest map reviewed that portrayed the project area was the USGS 1953 Alexandria, LA 1:250,000 Scale topographic map, which depicts a forested landscape prior to the inundation of the Toledo Bend Reservoir. The earliest reviewed map at a suitable scale to depict detail of the project area was the USGS 1957 Brookeland, TX 15-minute topographic quadrangle, which depicts a structure that is near the terminus of the landform overlooking Six Mile Creek and appears to overlap the current APE. However, the 1969 Brookeland, TX 15-minute topographic quadrangle indicates that the structure overlapping the project APE was no longer extant, and depicts the photorevised addition of the reservoir. By 1984, according to the Hurricane Creek, TX 7.5 ' topographic quadrangle, the project APE appears to have been devoid of forested vegetation.

Based on the results of the records review, the entire project area was considered to have a high probability for containing archaeological resources. This was due to the location of a previously documented site, 41SB58, within approximately $50 \mathrm{~m}$ to the northwest of the proposed development, and the presence of a historic structure depicted within the project APE.

\section{Newly Recorded Archaeological Resources}

One isolated find was recovered as a result of the project (Figure B-1). This consisted of historic surface artifacts intermixed with modern crushed gravel along the exposed shoreline of the Toledo Bend Reservoir, along the northern edge of the APE. A shovel test was excavated at the location of the surface artifacts, and demonstrated that there were no subsurface remains at this location. An additional two shovel tests were excavated in each cardinal direction surrounding the surface scatter of artifacts, where possible (Figure 4). This included two shovel tests to the west, and two shovel tests to the east. Only one shovel test could be excavated to the south due to the presence of a paved parking area associated with the boat ramp. No shovel tests could be excavated to the north due to the waters of the Toledo Bend Reservoir.

In total, two historic ceramic sherds and three pieces of crushed chert gravel were recovered from the ground surface at the isolated find (Figure 5). Both ceramic sherds were stoneware. One body sherd $(26.51 \mathrm{~g})$ has both salt-glazed exterior and interior surfaces and dates broadly between 1780 and 1925 (Greer 1999; Ketchum 1983). The second sherd $(11.61 \mathrm{~g})$ is also salt-glazed on both the interior and exterior surfaces, however, a chromatic glaze is also present on the exterior surface. This second body sherd dates between 1930 and 1970 (Faulkner 2000).

Three pieces of non-local chert were collected among the gravel at the existing boat ramp. These were evaluated for their potential to represent prehistoric materials, but all three appear to represent crushed gravel and do not appear to be prehistoric in origin. None of the items have clear flake scars with bulbs of percussion, and the two larger fragments have clear impact fractures. The larger (226 g) also has trace amounts of silver paint present. The second piece of gravel $(100.11 \mathrm{~g})$ also exhibits impact fractures. This piece also has a good deal of retaining cortex ( 3 of 4 sides and the end) which suggests that the piece has undergone little alteration besides crushing. Finally, the smallest piece of chert (34.58 g) exhibits no clear bulbar scars, and a remaining cortical edge shows no evidence of striking platforms.

In conclusion, the isolated concentration of historic artifacts may be associated with a historic structure depicted at the location of the project APE on historic mapping dating between 1957 and 1969. 
This page has been removed intentionally to protect sensitive

\author{
cultural materials
}

Figure 4. Isolated Find schematic map. 


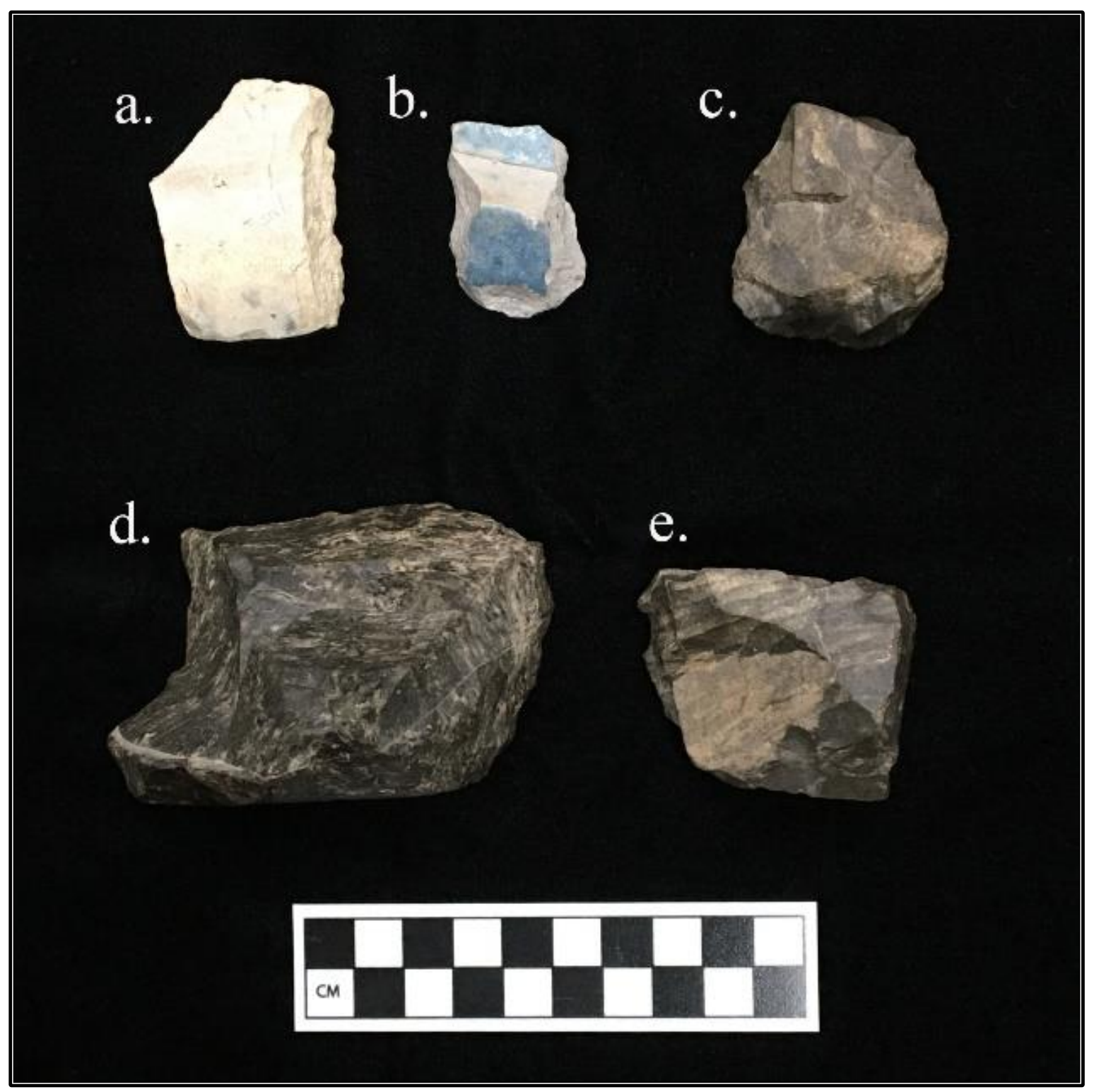

Figure 5. Items collected during the survey: a) salt-glazed stoneware; b) chromatic glaze and salt stoneware; c) chert specimen \#3-34.58 g; d) chert specimen \#1-226 g; and e) chert specimen \#2-100.11 g. 
One of the recovered artifact types exhibits a broad temporal span, roughly dating between 1780 and 1925, and the other was a twentiethcentury type, dating between 1930 and 1970 . This suggests that these materials could be related to an early to mid-twentieth-century homesite. However, these materials were recovered from a surface context and in association with imported gravels, and no subsurface materials were located. Additionally, the full range of architectural materials and other functional categories usually associated with historic home sites were not found within the project area. It is therefore also possible that these artifacts might have been carried into the project area from another location and might not be associated with the mapped historic structure.

Based on the data from this isolated find, the isolated find does not appear to have the necessary characteristics to be eligible as a State Archeological Landmark or to be eligible for listing in the NRHP. The sparseness of cultural materials and the lack of context suggest that the resource has no research potential. For this reason, this resource is recommended as not eligible for designation as a State Archeological Landmark or for listing in the NRHP.

\section{CONCLUSIONS AND RECOMMENDATIONS}

C RA personnel completed a records review and cultural resource survey for the proposed expansion of the existing Six Mile Boat Ramp in Sabine County, Texas, under contract with the SRA-TX on property owned by the SRA-TX adjacent to the Toledo Bend Reservoir. The work was performed under Texas Antiquities Permit Number 9155. This work was performed to assist the SRA-TX in complying with Section 106 of the National Historic Preservation Act of 1966 as an applicant for a Section 404 Clean Water Act Permit from the US Army Corps of Engineers, and the provisions of the Texas Administrative Code regarding archaeological resources on public lands. The SRA-TX is considered a political subdivision of the State of Texas, and it therefore has a responsibility to provide the TAC an opportunity to review projects that may affect potential or designated archaeological sites.

The proposed expansion included the addition of a handicap accessible floating boat ramp, the clearing of approximately 0.4 ha of trees, the construction of a parking area, the addition of a vault toilet, the addition of two tables on concrete platforms, and the clearing of trees along the shoreline to provide an enhanced scenic view. The construction of these facilities would have a small impact horizontally, and most of the construction would have a very shallow vertical impact with the exception of the vault toilet which would require the excavation of a pit. In order to provide some flexibility in siting these facilities, the direct APE for this project was considered an area demarcated to the south and west by the SRA-TX property line, and to the north and east by the existing shoreline of the Toledo Bend Reservoir. It is estimated that the direct APE for this project includes 1.2 ha of which approximately 0.3 ha was under pavement at the time of the survey, and thus 0.9 ha underwent survey. The locations of the proposed developments were not finalized by the completion of the field investigation and reporting, but they will be entirely within the direct APE as defined for this project. The vertical APE for archaeology would include all the sediment above the subsoil within the direct APE since it is unclear where the vault toilet will be placed. The impact to historic-age above-ground resources was also taken into consideration, and it was determined that the visual APE was limited to the direct APE as defined above. There were no buildings or structures over 50 years in age within the visual APE for this project

The records review for this project was conducted on October 18, 2019, and the fieldwork was conducted on November 19, 2019, pursuant to archaeological field standards published by the CTA and adopted by the THC, acting on behalf of the SHPO. This report follows the short report format as outlined by the CTA's Guidelines for Cultural 
Resource Management Reports. All materials associated with this project will be prepared for permanent curation at Stephen F. Austin State University.

Based on the results of the records review, the entire project area was considered to have a high probability for containing archaeological resources. This was due to the location of a previously documented site, 41SB58, within approximately $50 \mathrm{~m}$ to the northwest of the proposed development, and the presence of a historic structure depicted within the project APE. One isolated find was recovered as a result of the project. This consisted of historic surface artifacts intermixed with modern crushed gravel along the exposed shoreline of the Toledo Bend Reservoir, along the northern edge of the APE. Based on the data from this isolated find, it does not appear to have the necessary characteristics to be eligible for listing in the NRHP, or as a State Archeological Landmark. The sparseness of cultural materials and the lack of context suggest that the resource has no research potential. For this reason, this resource is recommended as not eligible for designation as a State Archeological Landmark or for listing in the NRHP, and it is recommended that the proposed project be considered cleared from a cultural resource perspective.

If any previously unrecorded archaeological materials are encountered during construction activity, the THC should be notified immediately. If human skeletal material is discovered, the construction activities should cease, the THC and local law enforcement should be contacted immediately, and THC guidelines should be followed.

\section{REFERENCES CITED}

Billington, Dora M.

1962 The Technique of Pottery. Hearthside

Press Inc., New York.

Cameron, Elisabeth 1986 Encyclopedia of Pottery and

Porcelain, 1800-1960. Facts on File

Publications, New York.

Dodd, Arthur Edward

1964 Dictionary of Ceramics. Philosophical

Library Inc., New York.

Faulkner, Charles H.

2000 Historical Archaeology Laboratory

Manual. Department of Anthropology,

University of Tennessee, Knoxville.

Greer, Georgeanna H.

1999 American Stonewares: The Art \&

Craft of Utilitarian Potters. 3rd Ed.

Schiffer Publishing, Atglen,

Pennsylvania.

Ketchum, William C., Jr.

1983 Pottery and Porcelain. Alfred A.

Knopf, New York.

Lewis, Griselda

1950 English Pottery. Pellegrini and

Cudahy, New York.

Lofstrom, Edward U., Jeffrey P. Tordoff, and

Douglas C. George

1982 A Seriation of Historic Earthenwares

in the Midwest, 1780-1870. Minnesota

Archaeologist 41(1):3-29.

Majewski, Teresita, and Michael J. O'Brien

1987 The Use and Misuse of Nineteenth-

Century English and American

Ceramics in Archaeological Analysis. In

Advances in Archaeological Method and

Theory, Volume 11, edited by Michael

J. Schiffer, pp. 97-209. Academic Press, New York.

South, Stanley

1977 Method and Theory in Historical Archaeology. Academic Press, New York. 


\section{United States Geological Survey}

1953 Alexandria, LA 1:250,000 map.

United States Department of the

Interior, Washington, DC.

1957 Brookeland, TX 15-minute quadrangle map. United States Department of the Interior, Washington, DC.

1969 Brookeland, TX 15-minute topographic quadrangle map. United States Department of the Interior, Washington, DC.

1984 Hurricane Creek, TX 7.5-minute quadrangle map. United States Department of the Interior, Washington, DC. 
Page intentionally left blank. 


\section{APPENDIX C. HISTORIC ARTIFACT INVENTORY}


Page intentionally left blank. 
Table C-1. Historic Materials Recovered.

\begin{tabular}{|c|c|c|c|c|c|c|c|c|c|c|c|c|c|c|c|c|}
\hline Catalog \# & Field Bag & Site & Unit \# & Depth & Group & $\begin{array}{l}\text { Class } \\
\text { Definition }\end{array}$ & $\begin{array}{l}\text { Type } \\
\text { Definition }\end{array}$ & Combned Attributes & Burned & $\mathrm{Ct}$ & Wt (g) & $\begin{array}{l}\text { Vessel } \\
\text { Part }\end{array}$ & MinDate & MaxDate & References & Comments \\
\hline SFA2020.1.1 & 001 & 41SB58 & GSC & $\begin{array}{l}0-0 \mathrm{~cm} \\
\text { bgs }\end{array}$ & $\mathrm{D}$ & Ceramics & Stoneware & $\begin{array}{l}\text { Salt glazed exterior, } \\
\text { Salt glazed interior }\end{array}$ & No & 1 & 26.51 & Body & 1780 & 1925 & $\begin{array}{l}\text { Greer 1999; } \\
\text { Ketchum } 1983\end{array}$ & $\begin{array}{l}\text { shoulder sherd; vessel } \\
\text { utility but type } \\
\text { indeterminate }\end{array}$ \\
\hline SFA2020.1.1 & 001 & $41 \mathrm{SB} 58$ & GSC & $\begin{array}{l}0-0 \mathrm{~cm} \\
\text { bgs }\end{array}$ & $\mathrm{D}$ & Ceramics & Stoneware & $\begin{array}{l}\text { Chromatic glaze } \\
\text { exterior, Salt glazed } \\
\text { interior }\end{array}$ & No & 1 & 11.61 & Body & 1930 & 1970 & Faulkner 2000 & $\begin{array}{l}\text { exterior blue }+ \text { salt } \\
\text { glaze; vessel type } \\
\text { indeterminate }\end{array}$ \\
\hline
\end{tabular}

*General surface collection 